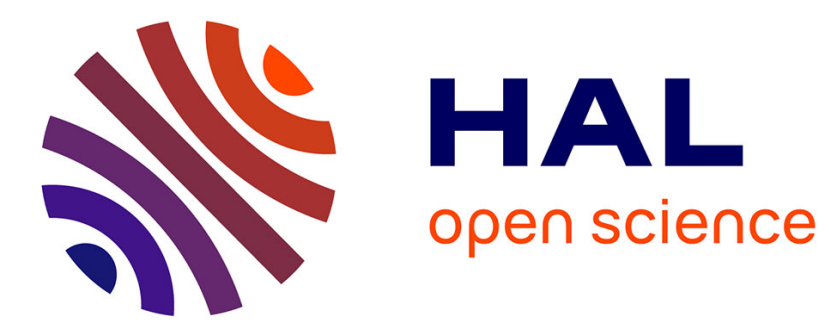

\title{
Informal help from family support workers for families in France
}

\author{
Bernadette Tillard
}

\section{To cite this version:}

Bernadette Tillard. Informal help from family support workers for families in France. Child \& Family Social Work, 2016, 10.1111/cfs.12296 . halshs-01427568

\section{HAL Id: halshs-01427568 \\ https://shs.hal.science/halshs-01427568}

Submitted on 21 Jun 2017

HAL is a multi-disciplinary open access archive for the deposit and dissemination of scientific research documents, whether they are published or not. The documents may come from teaching and research institutions in France or abroad, or from public or private research centers.
L'archive ouverte pluridisciplinaire HAL, est destinée au dépôt et à la diffusion de documents scientifiques de niveau recherche, publiés ou non, émanant des établissements d'enseignement et de recherche français ou étrangers, des laboratoires publics ou privés. 


\title{
Informal help from family support workers for families in France.
}

\author{
Bernadette TILLARD \\ Univsersity Lille1, CLERSE - UMR 8019 \\ bernadette.tillard@univ-lille1.fr
}

\begin{abstract}
Providing educative help at home means that professionals have to enter into the intimacy of families and share daily tasks, often for a long time. Family support workers (FSWs) spend many hours alongside parents helping them with their domestic and parenting tasks. This paper reports findings from an ethnographic study in which the researcher notes and gathers personal accounts relating to material and non-material exchanges between professionals and parents. It analyses the various forms of exchanges between families and FSWs that are permitted, tolerated or excluded by employers. It shows the informal side of professionals working with parents at home.
\end{abstract}

\section{KEY WORDS:}

Family support, ethnography, social work (international), Professional ethic issue.

\section{INTRODUCTION}

\section{Parenting support}

Since the late 1990s, both in France and Europe, parenting support plays a role of renewed importance in educational interventions, particularly in the field of child protection (Martin 2014). The demographic study carried out by Deborah Ghate and Neil Hazel (2002) describes the three sources and three types of support received by families living in precarious conditions: firstly, informal support provided by the extended family, friends and neighbours, then the semi-formal support provided by the neighbourhood-based sector and the voluntary sector and finally, formal support from professionals working in the universal and targeted services.

Even though the quantitative study takes into account the universal services, the authors identify the fact that a significant proportion of parents receive no support whatsoever, whether it be formal or informal. In the qualitative part of their research, they report of parents who consider that the professional support provided is useless. Their main argument is that the support provided "didn't give practical help" (46\%) (Ghate \& Hazel, 2002, p. 172). 
This issue is also brought to light in other studies. For Karen Healy et al., (2011), combining both moral and practical support in interventions also means that the measure is perceived favourably.

According to Ghate \& Hazel, other reasons for dissatisfaction also play an important role, such as no home visits (34\%) or the team being 'not understanding or sympathetic' $(36 \%)$. These issues and the related accounts indirectly underline the fact that the families need the professionals to reach out to them and that they expect them to be sympathetic and attentive to all their needs. This perspective is adopted by those professionals who wish to improve "parental involvement in the decision to intervene" (Boutin \& Durning, 1999, p. 41). As underlined by Philippe Lyet (2013), congruence between the needs of the user and what is possible during interventions is difficult to achieve. This is because the possibilities for action "are never quite adequate as they reduce a complex situation to one or a few aspects, whereas a user's situation and the possible interventions have many different dimensions" (Lyet, 2013, p. 56). To better understand the users, those intervening often opt for an ecosystematic analysis of the family situations (Kemp et al. 2014; Gray 2002) and an empowerment approach (De Montigny \& Lacharité 2012; Lacharité \& Goupil 2013). Also, some programmes have tried to implement an approach that offers both "practical assistance and the understanding of parents' own needs" (Masson, 2012, p. 373).

For Karen Healy et al. (2011), in Australia, the positive attitude of social workers towards parents greatly contributes to the latters' involvement. When social workers give parents the feeling of being listened to and encouraged, when they decide on and achieve attainable goals with them, the authors explain that they enter into a virtuous circle where the result of the measure strengthens parental involvement. This also seems to be the case when the measure is more restrictive (Healy et al., 2011, p. 287). However, in most contracts with families, the alternative between out-of-home care and educational support does not comply with the legal definition of the contract as presented by Catherine Taglione (2013). The author points out that the contract implies "an inner tendency to commit oneself" (Taglione, 2013, p. 31) in the educational relationship and that this cannot realistically be compatible with the threat of outof-home care. Jill Schreiber et al. (2013) underline the fact that for the parents met during research, it is the interpersonal skills of the professionals that have the most impact on their commitment. Conversely, the use of a coercive method leads to a superficial involvement of the parents, who "play the game" or pretend to cooperate (Schreiber et al., 2013, p. 708). The same conclusion is drawn by Gary Dumbrill (2006) who investigated how families perceive the power of social workers. The families distinguish between the use of "power over" them 
and "helping them gain power". This difference largely determines their attitude, which varies depending on the person they are speaking to as well as their current situation. The author discerns a "fighting" attitude or a superficial commitment (parents playing the game) that prevails in the case of coercive power. On the contrary, a social worker who really listens to the parents is more likely to transform superficial commitment into real involvement. In the most favourable cases, it will immediately lead the parents to work with the social worker. June Thoburn (2010) points out that "'uncooperative' parents and adolescents can be encouraged to become engaged with professionals if the services provided seek to meet all their needs and do not focus more narrowly on risks factors or anti-social behaviour" (Thoburn, 2010, p. 13). Finally, Susan Kemp et al. (2014) insist on a better balance between the two concerns that are always present in child protection situations; on the one hand reducing the risks and on the other hand providing parenting support. These authors recommend intervention methods that correspond to the competency of the parents. Not only does this positive strategy facilitate the parents' cooperation and lead to better results, but it also contributes to a form of positive treatment of the social workers themselves: the latter feel better in their work, which in return helps maintain a favourable attitude with regards to the involvement of the parents.

The professionals at the heart of this article are "Techniciennes d'intervention sociale et familiale" (TISFs). This French profession is translated in the rest of the document by the English term "Family Support Workers" (FSWs). The article shows to what extent FSWs simultaneously provide the contracted formal support as well as informal support that goes beyond the expectations of the employers. It is therefore different from the work of Ghate and Hazel that separates the informal help from family and friends and the formal help from professionals. Based on an ethnographic study, we show the intertwining of formal and informal support that can be seen through the exchange of objects, small services and mutual kind gestures. This perspective can be compared to two disciplinary trends: firstly, psychosociology, when it explores the distinction between the work required by the employer and the real work carried out by the professional (Dejours 1998) and secondly, economic ethnography, when it deals with the overlap between work and personal and emotional commitments (Zelizer 2005; Zelizer 2010; Weber \& Gramain 2003). We have therefore addressed these issues in the domain of child protection, with regards to a profession that works very closely with families. How do the FSWs carry out these exchanges? What control do their employers have over these exchanges? 


\section{Family Support Worker (FSW): Picture of a profession}

In France, around 8,000 people work as FSWs. This profession is just above the lowest level of qualification certified by a state diploma (Level IV); it lies between the less qualified job of Auxiliaires de vie sociale (Level V) and that of most social care workers (Level III: assistant de service social, éducateur, etc.). Most of FSWs are women employed by non-profit agencies, which are private structures. They have preventive and educative missions in the families' homes, and participate in domestic and up-bringing tasks for several hours each week. The non-profit agency is commissioned for a certain number of hours that can be renewed. Two public institutions can mission them:

- The local authorities in charge of child protection in France: the parent is considered not fit to bring up their child or children and neglectful, and the social workers consider that the FSW' intervention can avoid out-of-home care.

- The State via the family benefits offices (Caisses d'allocation familiale) or the health insurance system. In these cases, intervention is necessary because of a temporary or new difficulty (birth of twins, someone ill in the family, the death of the father or the mother, a separation).

The structure that prescribes the intervention pays the non-profit agency that employs the FSWs. However, in all cases, the families must pay part of the fee and the amount is calculated according to the family's income.

\section{METHOD}

The exchanges discussed in this paper were observed during an ethnographic study of relations between FSWs and families conducted as a participative observation (Autor, 2010). Two non-profit agencies opened their doors. Five FSWs volunteered to take part in the research. The nine families were also asked for their agreement prior to our arrival. The families observed - chosen from amongst those with whom the volunteer FSWs work - were approached via their employing agencies who also contacted the parent(s) in order to obtain their consent. Care was taken when identifying the research participants to ensure that several types of situation were included, both in terms of the family situation (couples with children, single-parent families) and the aim of the intervention within the family (avoid out-of-home care or answer a temporary difficulty).

With the parents, FSWs and Agencies' agreements, the ethnographic observation was carried out similarly to the way a trainee FSW on placement works, in other words, by taking part in the FSW's daily activities within the families. Between one and two half-days per week were 
devoted to the study over five three-month periods. Observation during these sessions, which ranged in length from between two and six hours, was sometimes conducted in the presence of pre-school children and sometimes with the whole family. Brief notes were taken down in a small notebook. Just a few words or expressions were jotted down and once the session was over these were expanded upon using immediate memories of the half-day, as is usual in ethnographic methodology.

At the end of each stage of the research (around three months), separate semi-directive interviews were conducted with the FSW and the family. These served to consolidate this observation method. With the family, the subjects discussed were: the beginning of the FSW's intervention in the family, FSWs previously present in the family, other family support networks (relations, friends, social care workers), the nature of exchanges between the FSW and the family, family assistance during the parents' childhoods. With the FSW, the interview related to questions concerning the choice of profession (motivations, previous career path, prospects), exchanges between the family and the FSW, the analysis of the family situation observed, their role within this family.

In each agency, the director and staff members responsible for coordination were also interviewed about the agency's objectives, human resources management, the beneficiaries and financial aspects. Other agency managers or experts responsible for this issue, along with the main financial backers (family benefits offices or local authorities) were also interviewed at the beginning of the research.

In the context of this study, which has its theoretical roots in ethnography, the field is not a confined area, "limited in size", Augé (1979, p. 197) but two geographically distant spaces. However, the fundamental principles of the ethnographic approach are maintained. For example, to become sufficiently familiar with the families and professionals, the observation period has to last a certain time. Each professional and each family within which they intervene are met repeatedly over a three-month period. Therefore, the total contact time with the same FSW and the same family is around 48 hours spread over the 3 -month period. This length of contact means that relationships can be established that go beyond the formal framework of the research. It is within such a context that material and informal exchanges between families and professionals can be observed.

To preserve the anonymity of the professionals and the families, all names have been changed. For the same reason, certain situations have been reassigned to several fictitious people. 


\section{FINDINGS}

The exchanges between the FSWs and the families take three different forms. We will discuss in turn the exchanges controlled by the employers, those included in the daily work and then those that lie outside the scope of the FSWs' work.

\section{The employer's control over the exchanges}

\section{"Do with nothing"}

In several associations, the managers do not want the FSWs to bring anything from their own home. They provide a minimum of items that they are allowed to use with the families. "They have been trained to do with nothing. However they do sometimes exchange things, "I know a family that has to get rid of some baby clothes, do you need any for one of your families?" We aren't there to bring things, we're there to work with people and that's very evident in the FSW' behaviour... We're not there to provide charity, we're not there for the purposes of paternalism even if there's nothing to eat, we can manage with nothing, but we won't bring tins of peas from home, because it isn't educational. It's probably more educational to go with a mother to a charitable organisation and the "restos du cour" (soup kitchens) or to seek emergency social aid, with the aim of helping the family become independent again. In these kinds of circumstances, these things may be considered as educational."

In France, the fear of receiving "charity" is a sensitive issue in social care work. In fact, professional support has been developed in certain opposition to the voluntary help provided by catholic institutions. Although not wanting to provide this kind of help, FSWs mobilise charity organised by the voluntary sector. Learning how to use private support systems is an educational objective, comparable to a form of autonomy. These words explain in their own way that when material aid is necessary, it must not come from the FSW. An exception is made for the exchange of clothes, where they can act as intermediaries between different families; the term "exchange" is used as the family can either be a donor or a recipient and this makes the situation acceptable. This mutual help system is also used by another agency.

\section{A place that makes exchange possible}

One agency plays the role of mediator between FSWs and families. It has a room on the second floor of the agency to stock items that can be exchanged. Martine, who works in the agency, asks the parent's permission to take some baby items that the family don't need any more and want to throw away. Martine takes them and puts them in this room that she calls the "attic". "Yes, we sometimes give things when, for example, parents have twins or they 
can't buy the things they need, we can go to the attic and take what's required". The "attic" plays an important role in the exchanges. Every month, the attic is filled up and emptied, highlighting the agency's role in an exchange network that often involves the circulation of items from families experiencing temporary problems to more destitute families requiring longer term assistance. A type of barter takes place and no money changes hands. This transit via the attic erases the donor's identity, with reference to the theory of gifts expounded by Marcel Mauss (1923). The gift thereby becomes anonymous, stripped of the soul of the donor, and this conveys the mission of the agency, which sees itself as a link in a chain of solidarity between families. When they take an item to a family, FSWs can refer to the attic. It becomes an object that has been left to the agency and that has been selected for the family, but it is not a personal item that she is getting rid of. This gift "decontamination" technique not only rids the object of the identity of the previous user, but also minimises the debt: it is an object that is no longer wanted and that is being recycled. It is not a purchase that highlights the destitution of the receiving family.

The other advantage of the attic is that it not only concerns giving and receiving, but it also allows the family to participate by bringing items to the agency. One of the agency's coordinators underlines this fact, "It also helps the family to integrate, as they get involved in the agency's work and the outside world". The attic covers the three aspects of giving (giving, receiving, giving back), avoids a face-to-face situation between the FSW and the family and introduces the idea of a society through a form of redistribution in which everyone can take part in one form or another, to varying degrees and at different points in their lives.

Despite the role of the agencies, either facilitating or avoiding the transactions, various types of exchanges are present during working hours but do not necessarily come to the employer's attention. These creep into daily life and play a role in the face-to-face between the professional and the family.

\section{Exchanges embedded in work}

\section{Exchange of safe resources}

When FSWs are commissioned for temporary help, they may be welcomed, but often they are just tolerated. When the intervention is prescribed by a child protection agency, the family often feel a certain social discredit and resent the FSW's work. Nevertheless, some simple gestures of hospitality gradually appear. They then become routines and allow for exchanges 
that go beyond the usual conventions. For example, every day Lucienne arrives at the apartment, Ghyslaine, the mother, offers the FSW a cup of coffee. During these moments, they talk about the morning's timetable and the important issues that will be on the agenda in the coming weeks: the little one's doctor's appointment, relations with educators from the children's home, the violent behaviour of a teenager, etc. Whilst they discuss and draw up the timetable for the morning or the coming weeks, Ghyslaine regularly asks Lucienne for a cigarette. This exchange takes place during these times of great concentration and of important and sometimes bitter discussions between the two women. One day, when we are about to leave the apartment, Ghyslaine calls Lucienne back and offers her a packet of her favourite cigarettes. "Here Lucienne, that's for all the ones I've cadged off you". Lucienne refuses. "No Ghyslaine, that's too much", but Ghyslaine insists. Lucienne continues to hesitate... The emotion of both women is perceptible. Finally Lucienne accepts the cigarettes. In this context, the conviviality of the coffee-cigarettes exchange (the coffee offered by Ghyslaine - the mother, the cigarette contributed by Lucienne - the FSW) appears to be a "safe resource", an "island of safety" (Goffman 1988) that through the conduct of a codified activity paves the way for dialogue about some of the dramas the family has gone through. The cup of coffee and the chair combined with the usual words of hospitality correspond to the gestures identified by Goffmann, "The manifestations of courtesy, especially amongst those requiring small offerings and assistance" (Goffman, 1988, p. 111).

In these moments over a coffee, the FSWs talks to the families about their own private life, with another aim. Reference to private life may correspond to an attempt to remove the stigmatising aspect of most social work interventions by offering the chance for comparison and showing that the FSW's family and the one they are supporting share common events and the same social reality: putting up the Christmas tree at their own house, talking about a television programme watched the day before, etc. Sometimes, it is empathy that leads to sharing a private situation similar to the one being experienced by the family in order to make it seem less dramatic, to show understanding, tackle isolation, offer advice or encourage the family to get over a serious ordeal. When the FSW's private life surfaces within the family's life, it is a comparison platform that the family is offered, an aspect that Ireys, Devet and Sakwa (2002) identify as useful support (Ireys et al., 2002:156-157).

\section{Gifts and educative strategies}

Some exchanges take the form of gifts, but the following is actually an educative strategy. This example is of two little girls who have been suffering from head lice since the FSW first 
met them. One morning Cécile brings a bottle of anti-dandruff shampoo for Annie. She explains that it is an excellent product and describes the television adverts for it; this carries a lot of weight in a household where the television plays an important role. Annie seems happy to be given this brand shampoo, as it is usually the cheapest supermarket egg-based shampoo that is used in the house. Here, the "gift" is a kind of strategic device to persuade the mother that in spite of the quality of the product, she still has lice and not dandruff as she claims. Cécile would like to persuade Annie to take care of her lovely black hair, at the same time as treating the children.

Although Annie may believe it to be a gesture from one woman to another, encouraging her to take an interest in her appearance, Cécile is actually using it as a means to educate her. The "gift" is therefore an object used as part of a strategy designed to persuade the mother to take care of herself. The gift is not formally wrapped up as a present, but it is a well-publicised brand product and therefore, in the mother's eyes, it is highly valued. A counter-gift is expected by the FSW. This consists in a change in the mother's behaviour. This is the countergift described by Paul Fustier. "These attempts at securing changes have the value of countergifts, they demonstrate a desire to make the carer or social care worker happy, and this is in return for the gift (Fustier, 2000, p. 99).

The advantage for the FSW is twofold: an educational one by avoiding the transmission of lice from the parents to the children, but also a personal one by increasing the comfort of their working conditions. In fact, for several months, Cécile has been "receiving" lice that she could have done without. They have been upsetting her relationship with her own children and led her to change her hairstyle. She has had her hair cut much shorter, to make it easier to look after and to limit the spread of lice. The work of the FSW includes sharing all aspects of family life, such as washing, carrying the children and cooking. During these activities, the physical distance that has to be kept to avoid catching lice may make it difficult to look after the children, not forgetting the fact that it would be likely to offend the mother. In this family, the issue for the mother in contact with the FSW is to learn how to take care of herself and her children. We are at the heart of a relationship that relates to primary needs: learning to cook, personal hygiene, etc. The reality of the daily lives of FSWs in contact with families leads to unplanned sharing, unwanted gifts and the transfer of signs or stigmas that make them feel a certain proximity to the poverty they are rubbing shoulders with and a form of contamination by poverty permeating through to their private lives. In care tasks, this fear of contamination is common (Véga 1999). 
The items brought by the FSWs into the families do not follow the usual traditions of giving gifts. In general, a present is covered with wrapping paper, tape and a bow... "One never offers a present any old way" (Montant, 1998, p. 452). Contrary to these customs, the gifts are not wrapped and are given without ceremony, underlining the links with the purpose of the job. So, on Logan's birthday, the FSW says to the child as soon as she arrives: "Happy birthday Logan. Look at what I've brought you!" The child comes forward and laughs at the thought of what he hopes to find. He takes the foam ball from the plastic bag and the three of them start playing with it.

At the heart of this material gift can be interpreted another type of gift described by Paul Fustier: that of individuation. Clues such as remembering the birthday associated with the gift for such an occasion "show to the person being cared for that they are not just one among many others or part of a category of patients, disabled children / children with problems, homeless people, etc. They are recognised as an individual, as a subject having an identifiable place in the professional's thoughts" (Fustier, 2000, p. 98).

Also, the object was chosen to encourage stimulation exercises for this disabled 4-year old child. The ball becomes more legitimate in as far as it is integral to a motor activity appropriate for the child.

\section{When the FSW receives}

In some cases, it is the professional and not the family who receives. Here are several examples of instances where the FSW is the recipient. Every week, Anne goes to work in a large family. The parents take care of the weekly shopping whilst Anne looks after the children who are not at school. When the observation begins, habits have already been established. Séverine and her husband suggest that at the same time as doing their own shopping they buy some meat from the butchers nearby - with a reputation for being cheaper than the supermarket - for Anne and her own family. What should they bring back? The FSW pays the parents back as soon as they return. Unlike the two previous families, the proposal is not strictly speaking an object, but the exchange of a service between two families in the same socio-economic class, both keen to be well organised in order to facilitate their daily lives and balance their budgets. There is no financial outlay required, although sometimes...

However, irrespective of the families' socio-economic class, families sometimes show signs of consideration or attention towards the FSW that go beyond the ordinary obligations 
associated with courtesy and welcome. For example, Martine, who is on sick leave, gets at least one phone call every week from a family concerned about her health. This takes place in a context where both protagonists are aware of the fact that they have moved beyond the professional framework.

\section{Private exchanges and public recognition}

Exchanges about private life can be particularly noticed when the FSW has been working close to a suffering family for a long time. The example below describes the case of extended support for a very sick mother. "After a while she couldn't get upstairs any more. I asked her if she thought it would be a good idea to change a certain bed and then, the following week, I suggested something else. She said to me "I trust you with everything, do as you think best". She was becoming blind at the end and was lying downstairs on a bed in the living room. It was a normal family like yours and mine. One morning I turned up in a good mood because I'd just become a grandmother and I'd brought some photos to show her. I thought it would be a happy moment and it'd give us something else to talk about. It was her husband who opened the door. She had died in hospital that night. He asked me to stay to tidy the living room and make space for the coffin. He also asked whether I would mind making some soup for his sisters-in-law who were due to arrive... I was very flattered because in the death announcement they put "Marion, her social care worker and best friend".

In this situation, the FSW brings an aspect of her private life to distract attention away from the illness. The compensation will be the symbolic and public recognition of the relationship built up between the two women. The family recognizes on the one hand, the role of the professional and on the other hand, the special relationship that existed between them.

\section{Voluntary work and kinship}

In contrast to gifts existing within the context of work, there are those that professionals clearly identify as falling outside the sphere of work. This FSW accompanied the last moments of a little girl: "One night, the parents called me at 3 o'clock in the morning; the little girl was slightly delirious, she was shouting and asking for me. It was clear that the end was near. The parents told me "Of course you don't have to come, but we wanted to warn you." I got dressed and left and a few minutes after I arrived, she died, still clutching her teddy bear. With the lady from an agency I'd met several times in the family, we washed her, dressed her and left her teddy bear with her. That day, I called work to tell them I wouldn't be 
in to cover my usual shift. I helped the parents with the arrangements. I didn't want to be paid for the day, it was "an extra" service." This service is therefore no longer considered as being part of her work.

At the heart of these exchanges on the periphery of the professional field, we observe that the proximity created between the FSW and families is anchored in the day-to-day reality of a helping and supportive relationship. This is similar to a type of maternal guidance that is precisely aimed at learning about the role of a woman within a traditional role in the household and alongside children. A mother puts it as follows: "An FSW is someone who helps morally, who talks to people, who improves morale [...]. In my case, it was she who taught me to sort washing, make balanced meals, manage my budget, keep accounts, etc. She came everywhere with me, like when she came with me to the town hall to look for somewhere to live... I've already told her that she is like a mother to me".

In this case, as in so many other situations, we have a mother who has had major problems throughout her childhood and who remains highly vulnerable as she has nowhere to live, she is financially dependent and her partner has left her. In the FSW, she finds a maternal type of professional support, which provides an element of continuity in a history marked by two different partners abandoning her whilst she was pregnant.

For the mother, the professional is taking a free place unoccupied by her own mother, as is the case for blind mothers met by Séverine Gojard (2003, p. 132). These situations show a paradox: the frame of imposed and contracted relations between child protection agencies and families creates the conditions of elected relationships between professionals and families.

\section{DISCUSSION}

\section{The art of giving}

The FSWs use different strategies to give without appearing to do so. In the multitude of situations in which giving gifts arises, several professional strategies surrounding the gift have been described in this paper. We can observe a desire to legitimise the gift, to minimise it, to organise reciprocity or to place it at the margins, or even, outside the field of the intervention. In many cases, the legitimisation processes consist in using the educational approach and integrating "the pluses" into professional ethics or professional objectives. Minimising the gift sometimes involves underlining the absence of financial outlay and sometimes avoiding any compliance with the traditional conventions associated with a gift. Various reasons may lie 
behind this gift depreciation. This manner of proceeding tends to emphasise the fact that one does not give, or one does not give "too much" to people whose financial resources do not allow them to reciprocate, something that would lead to a position that is too unequal, within a relationship between social care workers and families that is already inherently asymmetric.

\section{The persistence of unacknowledged exchanges}

Although their situations are not as precarious, the living conditions of the FSWs are not very far removed from those of the families they work for. They are poorly paid. They have often chosen this profession because they were not able to study to become a social worker or a nurse. They have therefore chosen a job involving social work and care and usually qualify for their job through an apprenticeship or a sandwich course.

Most of the exchanges mentioned during the interviews with the professionals made reference to other families that I was not studying or families where the FSWs did not work anymore. Similarly, the families met talk of exchanges with FSWs who have left the association or who no longer work for the families. However, an ethnographic observation shows the existence of informal aspects that are closely linked to the work. The discretion of the families and the FSWs preserves the reputation of FSWs in the eyes of their employers and other social workers. But above all, by staying in the background, it seems to be the informal part of the work that maintains the mutual trust necessary for FSWs to enter into the privacy of the families and their daily lives (Mozère, 1999). This point is also highlighted by Jacques Godbout, "giving requires the implied and the unspoken. The magic of giving can only operate if the rules remain unformulated. As soon as they are formulated, the carriage becomes a pumpkin, the king appears naked and the gift requires an equivalent" (Godbout, 2000, p. 11]. The expertise of FSWs and families with regards to gifts and counter-gifts can be interpreted as a tool to strengthen the bond. These exchanges always have an element of unpredictability. They illustrate the gap between what the employer requires and what the professional does to better serve the purpose of their work (Dejours, 1998). They also symbolise the acceptance of the FSW's presence and show the mutual commitment that is necessary for the parents to get involved in the educational purpose of the intervention. This is the strength of these exchanges.

However, the theory of giving also teaches us of the possible drifts. Even though none were observed during the ethnographic study, they cannot be totally excluded.

The commitment in the relationship with gifts and counter-gifts, includes the likelihood of leading to an escalation that may drive FSWs toward a sense of sacrifice. Marie-Christine 
Pouchelle (1998) described these emotional transactions, these gifts and the fear of a limitless commitment in an ethnographic observation of time management in hospitals. Perhaps the rhetoric and the know-how that minimize the act of giving and the value of objects are used by FSWs as a way of self-preservation. In this case, not giving "too much" is not only a form of respect for indigent families, but also a guarantee of not receiving "too much", in other words, it is a way of avoiding an uncontrollable inflation of objects, services and emotions.

Similarly, for June Thoburn, there is a risk of collusion between families and FSWs (Thoburn, 2010). Considering that they have a physically hard job, that they work alone in the homes and that they face difficult and complex situations, are the FSWs able to keep the necessary distance in all situations? If the answer to this question is no, then the educational objectives determined in the child's interest would become secondary.

There are therefore both benefits and risks involved in these gifts and counter-gifts. Faced with this, the FSWs experience contrasting work situations. Some employers are of no help at all, as they deny that this type of exchange exists by referring to strict professional standards. Therefore, the only assistance they can get is from those around them, in particular from the other professionals they are friends with.

Other employers are aware of this issue, but they do not have the financial resources to provide the necessary supervision to distinguish between exchanges that facilitate the intervention and those that threaten it. So they try to manage the problem by offering collective solutions, such as the attic, to give meaning to a transaction that goes further than the one-to-one discussion between the parents and the professionals and that introduces the notion of reciprocity in the exchange.

Whoever the employer, we can consider that this process of giving without seeming to is a skill that has been developed by this profession in direct contact with families. In the framework of this research, this skill facilitates their educational work with the families and allows the families to get involved, not just in the shared activities but also in the special relationship that is built up with the professional. 


\section{REFERENCES}

Augé, M. (1979) Symbole, fonction, histoire. Les interrogations de l'anthropologie. Hachette, Paris.

Boutin G. \& Durning. P. (1999) Les interventions auprès des parents. Innovations en protection de l'enfance et en éducation specialise. Dunod, Paris.

Dejours, C. (1998) Souffrance en France. La banalisation de l'injustice sociale, Seuil, Paris.

De Montigny, F. \& Lacharité, F. C. (2012) Perceptions des professionnels de leurs pratiques auprès des parents de jeunes enfants, Enfances, Familles, Générations, 16, 53-73.

Dumbrill, G. (2006) Parental experience of child protection intervention: a qualitative study, Child Abuse and Neglect, 30, 27-37.

Fustier, P. (2000) Le lien d'accompagnement. Entre don et contrat salarial. Dunod, Paris.

Ghate, D. \& Hazel, N. (2002). Parenting in poor environments. Stress, support and coping. Jessica Kingsley Publishers, London.

Godbout, J. (2000). L’Esprit du don. La Découverte, Paris.

Goffman, E. (1988) Les moments et leurs hommes. Editions de minuit, Paris.

Gojard, S. (2003) Soutien institutionnel et quasi-parenté. Un groupe de mères aveugles. In: Charges de famille. Dépendance et parenté dans la France contemporaine (eds. F. Weber, S. Gojard \& A. Gramain), pp. 98-133. La Découverte, Paris.

Gramain, A. \& Weber, F. (2003) Modéliser l'économie domestique, In: Charges de famille. Dépendance et parenté dans la France contemporaine (eds. F. Weber, S. Gojard \& A. Gramain), pp. 9-42. La Découverte, Paris.

Gray, B. (2002) Emotional labor and befriending in family support and child protection in Tower Hamlets, Child and Family Social Work, 7, 13-22.

Healy, K., Darlington, Y. \& Feeney, J. A. (2011) Parents' Participation in Child Protection Practice: Toward Respect and Inclusion, Families in Society: The Journal of Contemporary Social Services, 92, 3, 282-288.

Ireys, H.T., Devet, K. A. \& Sakwan, D. (2002) Family support and education. In Community treatment for youth: Evidence-based interventions for severe emotional and behavioral disorders (eds. Burns \& Hoagwood), pp. 154-175. Oxford University Press, New York. 
Kemp, S. P. Marcenko, M. O. Lyons S. J. \& Kruzich, J. M. (2014) Strength-Based Practice and Parental Engagement in Child Welfare Services: An Empirical Examination, Children and Youth Services Review, 47, 27-35.

Lacharité, C. \& Goupil, E. (2013) Les familles à problèmes multiples : interventions socioéducatives et enjeux éthiques. In: Traité d'éducation familiale (eds. G. BergonnierDupuy, P. Durning \& H. Join-Lambert) p. 425-442. Erès, Toulouse.

Lyet, P. (2013). Approche sociologique : la transaction sociale ou sortir de l'impasse et de la prestation individualisée. In: Contrat et contractualisation dans le champ éducatif, social et médico-social. (eds. C. Taglione), pp. 49-58. Presses de l’EHESP, Rennes.

Martin, C. (2014) Le soutien à la parentalité : une nouvelle politique en Europe ? Politiques sociales et familiales, 118, 9-22.

Masson, C. (2012) Social work the 'art or relationship': parents'perspectives on an intensive family support project. Child and Family Social Work, 17, 368-377.

Mauss, M. (1923) Essai sur le don. Forme et raison de l'échange dans les sociétés archaïques, Année sociologique. In Sociologie et anthropologie, Mauss M. (1989). PUF, Paris.

Montant, S. (1998) L'invention d'un code: de malaise à la justification », Ethnologie Française, XXVIII, 4, 445-456.

Mozère, L. (1999) Travail au noir, informalité : liberté ou sujétion. Une lecture de travaux relatifs à l'économie informelle. Paris, L'Harmattan.

Pouchelle, M.-C. (1998) "Ici on ne fait pas de cadeau". Partages du temps et don de soi à 1'hôpital, Ethnologie française, XXVIII, 4, 540-550.

Schreiber, J. C., Fuller T. \& Paceley, M. S. (2013) Engagement in Child Protective Services: Parent Perceptions of Worker Skills, Children and Youth Services Review, 35, 4, 707715.

Taglione, C. (2013). Approche juridique : de l'objet contrat à la prise en considération du processus de contractualisation. In: Contrat et contractualisation dans le champ éducatif, social et médico-social. (eds. C. Taglione), pp. 23-47. Presses de l’EHESP, Rennes. 
Thoburn, J. (2010) Towards knowledge-based practice in complex child protection cases: a research-based expert briefing, Journal of children'services, 5, 1, 9-24

Tillard B. (2010). Échanges entre familles et professionnelles. Don et contre-dons. Ethnologie française, XI, 1, p. 131-139.

http://www.cairn.info/resume.php?ID_ARTICLE=ETHN_101_0131

Véga, A. (1999) Un bouillon de culture: contagion et rapports sociaux à l'hôpital. Ethnologie française, XXIX, 1, 100-110.

Zelizer, V. (2010), Caring everywhere. In: Intimate labor. Culture, Technologies, and the Politics of Care (eds. E. Boris, R. Salazar Parrenas), pp. 267-279. Stanford University Press, Stanford

Zelizer, V. (2005), Circuits within Capitalism. In: The Economic Sociology of Capitalim (eds.V. Nee \& Swedberg R.), pp. 289-322, Princeton University Press, Princeton.

\section{ACKNOWLEDGEMENTS}

I am grateful to June Thoburn who helped me to translate Technicienne d'Intervention Sociale et Familiale (TISF) in an appropriate profession "FSW - Family Support Worker". The regional youth health programme is thanked for the funding of this study. I am grateful to Uriopss Nord-Pas-de-Calais for his useful partnership to meet the associations of TISF.

The main results of this paper have been published in a French anthropological journal (Tillard, 2010). The Editor of Ethnologie Française is thanked for her agreement of this further publication in English. 
